\title{
THE EFFECT OF THE APPLICATION OF THE BIOLOGICAL CONTROL AGENT EM1 ON GAS EXCHANGE PARAMETERS AND PRODUCTIVITY OF Pisum sativum L. INFECTED WITH Fusarium oxysporum SCHLECHT.
}

\author{
Adam Okorski ${ }^{1}$, Jacek Olszewski ${ }^{1}$, Katarzyna Głowacka ${ }^{2}$, \\ Sylwia Okorska ${ }^{2}$, Agnieszka Pszczółkowska ${ }^{1}$ \\ ${ }^{1}$ Department of Diagnostics and Plant Pathophysiology, Plac Łódzki 6, 10-727 Olsztyn, Poland \\ e-mail adam.okorski@uwm.edu.pl \\ ${ }^{2}$ Department of Physiology and Biotechnology of Plants, Oczapowskiego 1A, 10-727 Olsztyn, Poland
}

Received: 03.08.2010

\section{Abstract}

A pot experiment on different methods of EM 1 application was conducted in the period 2002-2004. The study was carried out under controlled growth conditions. The experimental factor was the method of EM1 application. Before application, the biological preparation EM1 was propagated as recommended by the manufacturer (Greenland).

The health status of the aboveground parts of 'Ramrod' pea plants was estimated at the flowering stage. The assessment of pea leaf gas exchange parameters (An, E, Gs, and $C i$ ) was made using a LI-Cor 6400 Portable Photosynthesis System. Soil application of EM1 combined with chemical control contributed to inhibiting Fusarium wilt of pea. Foliar application of EM1 combined with chemical control increased all gas exchange rates of pea leaves. Fusarium wilt of pea insignificantly decreased all gas exchange rates of pea leaves and the number of seeds per pod. The best method of EM1 application was soil treatment combined with chemical control, which increased all yield-related morphometric parameters of pea.

Key words: Fusarium oxysporum, gas exchange parameters, biological control, Pisum sativum L., EM1

\section{INTRODUCTION}

Conventional agriculture is characterized by the application of substantial amounts of pesticides and fertilizers, the effect of which is soil contamination, the disturbance of soil biological balance as well as indirect contamination of plant products with pesticides. The use of large amounts of chemicals in farming leads to reduced numbers and diversity of beneficial flora and fauna found in agricultural lands ( $\mathrm{S} \mathrm{t} \mathrm{r}$ a $\mathrm{n} \mathrm{g}$ e and $S \operatorname{cott}, 2005)$. A direct effect of the application of fungicides is the confirmed presence in nature of pathogen races resistant to individual active substances of fungicides and those in the case of which cross-resistance has been found. Biological control of plants can be an alternative that reduces adverse effects of fungicide application in farming. At the same time, cost-benefit analysis - assessment of supply and demand for products of plant origin - makes it necessary for food producers to adapt to market conditions. On the one hand, this leads to a reduction in the number of cultivated plant species and varieties, while on the other hand it forces optimal, in line with such cost-benefit analysis, application of plant protection agents and fertilization that use natural resources of ecosystems, which may slightly compensate high costs in agriculture. Therefore, we can currently observe the ever wider use of microbiological preparations which beneficially affect the growth of plants by enabling them to use unavailable forms of nutrients. The biological preparation EM1 (Effective Microorganisms) is a mixed culture of photosynthetic bacteria, lactic acid bacteria, and yeasts; it is characterised by low $\mathrm{pH}$ (below 3.5) and is enriched with hyphal fungi and Actinomycetales that naturally occur in them (D a i s s et al. 2008). As reported by D a ly and Ste w art (1999), in $1 \mathrm{ml}$ of EM1 concentrate there are a minimum of $10^{5}$ cells of Streptomyces albus, Propionibacterium freudenreichii, Streptococcus lactis, Aspergillus oryzae, Mucor hiemalis, Saccharomyces cerevisiae, and Candida utilis as well as Lactobacillus spp., Rhodopseudomonas spp., Streptomyces griseus, and Micromonospora chalcea at a lower concentration.

There are reports that confirm the beneficial effect of EM1 on the quality and yields of plants, physical and chemical properties of the soil, nutrient uptake by plants as well as on the numbers of other important bacteria and hyphal fungi which have a beneficial 
influence on plant growth ( $\mathrm{J}$ i 1 a $\mathrm{n}$ i et al. 2007; O k o r ski and Majchrzak, 2007; 2008). The aim of the present study was to determine the effect of the biological control agent EM1 on morphometric features, gas exchange parameters, and health of pea grown in a pot experiment.

\section{MATERIALS AND METHODS}

This pot experiment was carried out in a greenhouse of the University of Warmia and Mazury in Olsztyn, and the experimental factor was the method of application of Effective Microorganisms [EM1], which included the following treatments:

1. Soil application of EM1 combined with chemical control*;

2. Seed dressing with EM1 combined with chemical control*;

3. Plant spraying with EM1 combined with chemical control*;

4. Soil application of EM1 combined with seed dressing using Effective Microorganisms, and plant spraying with EM;

5. Control (without the application of Effective Microorganisms and plant protection agents);

6. Chemical control*

*(seed dresser T, fungicide Rovral Flo 250 SC, insecticide Owadofos 540 EC, herbicide Basagran $480 \mathrm{SL})$

The pot experiment was conducted in 3 series (2003-2005) in quadruplicate, under controlled conditions. Pea, (Pisum Sativum L.) cv. Ramrod, seeds were sown into pots at a depth of $5 \mathrm{~cm}, 6$ seeds per pot $(25 \mathrm{~cm}$ in height and $24 \mathrm{~cm}$ in diameter). Typical brown soil, obtained from the Tomaszkowo Research and Experimental Station, was used for seeding. Plant mineral fertilization was consistent with pea requirements and fertilization recommendations. Macronutrient media were used for plant nutrition: $-\mathrm{N}$ in the form of $\mathrm{NH}_{4} \mathrm{NO}_{3}, \mathrm{P}$ in the form of $\mathrm{Ca}\left(\mathrm{H}_{2} \mathrm{PO}_{4}\right) * 4 \mathrm{H}_{2} \mathrm{O}, \mathrm{K}$ in the form of $\mathrm{KCl}, \mathrm{Mg}$ in the form of $\mathrm{MgSO}_{4} * 7 \mathrm{H}_{2} \mathrm{O}$. In addition, a micronutrient medium was applied, at optimal amounts for leguminous plants, which contained the following micronutrients: $\mathrm{Fe}$ in the form of $\mathrm{C}_{10} \mathrm{H}_{12} \mathrm{FeN}_{2} \mathrm{NaC}_{8}$, $\mathrm{Mn}$ in the form of $\mathrm{MnC}_{12} * 4 \mathrm{H}_{2} \mathrm{O}, \mathrm{Zn}$ in the form of $\mathrm{ZnCl}_{2}, \mathrm{Cu}$ in the form of $\mathrm{CuCl}_{2} * 2 \mathrm{H}_{2} \mathrm{O}$, B in the form of $\mathrm{H}_{3} \mathrm{BO}_{3}$, Mo in the form of $\left(\mathrm{NH}_{4}\right) 6 \mathrm{M}_{07} \mathrm{O}_{24} * 4 \mathrm{H}_{2} \mathrm{O}$. Macro- and micronutrient fertilization was applied in 2 doses: prior to sowing and at the 4-5 true leaf stage.

Before the application of the biopreparation EM1, effective microorganisms were propagated in accordance with the manufacturer's recommendations
(Greenland). A $0.1 \%$ solution of effective microorganisms was stored in the dark for a period of 14 days at a temperature of around $20^{\circ} \mathrm{C}$. Seed treatment with effective microorganisms was done using a $0.2 \%$ solution of EM1; effective microorganisms were propagated during a 14-day incubation period in the dark at $20^{\circ} \mathrm{C}$.

\section{Morphometric analysis}

The analysis of the morphometric features of pea was performed at the maturation stage on 4 plants per pot (16 per treatment combination). The assessment of the morphometric traits included the following: plant height, first pod height, number of pods per plant, number of seeds per pod, and number of seeds per plant.

\section{Gas exchange parameters}

The gas exchange parameters were examined at the flowering stage of pea using a Li-Cor 6400 gas exchange system (Portable Photosynthesis System, Licor, Lincoln, NB, USA). Readings were taken at several-day intervals from middle-tier leaves, repeating each measurement 10 times. The following parameters were investigated: net photosynthesis rate An $\left(\mu \mathrm{mol} \quad \mathrm{CO}_{2} \mathrm{~m}^{-2} \times \mathrm{s}^{-1}\right)$, molar transpiration rate $E\left(\mathrm{mmol} \mathrm{H}_{2} \mathrm{Om}^{-2} \times \mathrm{s}^{-1}\right)$, stomatal conductance Gs [mmol $\left.\mathrm{H}_{2} \mathrm{Om}^{-2} \times \mathrm{s}^{-1}\right]$, and intercellular $\mathrm{CO}_{2}$ concentration $\left[\mu \mathrm{mol} \mathrm{CO} \mathrm{Cm}^{-2} \times \mathrm{s}^{-1}\right]$. These parameters were determined at a constant $\mathrm{CO}_{2}$ concentration of $400 \mathrm{ppm}$ and a light intensity of $1000 \mu \mathrm{mol} \mathrm{m} \mathrm{m}^{-2} \times \mathrm{s}^{-1}$. The source of photons was a LED Light Source emitting light with the main peak wavelength of $670 \mathrm{~nm}$ and the lower peak wavelength of $465 \mathrm{~nm}$.

\section{Health examination}

Health assessment of the above-ground parts of pea was performed in accordance with the modified scale of H ill s trand and A u ld (1982). This health assessment of pea served to calculate the infection index using McKinney's formula ( $\mathrm{E}$ a c i c o w a , 1969). Small segments were excised from infected plants in each treatment combination, and they were subsequently used for microscopic observation and mycological analysis. Immediately after sampling, the plant material for microscopic examination was manually cut into small pieces and fixed in $2.5 \%$ glutaraldehyde for 1 hour. Next, the sections were partially dehydrated in ethanol series (from 10 to 70\%). The specimens so prepared were stained in a $1 \%$ safranin solution for 30 seconds and transferred onto a microscopic slide. The stained sections were analysed in a drop of glycerol under a light microscope (OPTA - TECH MN - 258/358) (10 $\mu \mathrm{m}$ scale). The stem segments used for mycological analysis were washed in distilled water, and then sterilised in 50\% ethanol solution for 30 
seconds and in $0.1 \%$ sodium hypochlorite solution $(\mathrm{NaOCl})$ for another 30 seconds. Subsequently, after the segments were rinsed in sterile water three times and dried thoroughly, six $0.5 \mathrm{~cm}$ sections were placed on each sterile Petri dish with solidified potato-dextrose-agar medium. After 5-day incubation at a temperature of $24^{\circ} \mathrm{C}$, the grown fungal colonies were inoculated onto potato-dextrose-agar medium.

\section{Statistical analysis}

Statistical calculations were performed using the STATISTICA software package (Data Analysis Software System), version 6, StatSoft, Inc. (2006) www.statsoft.com, by means of the analysis of variance, with Duncan's test. The significance of differences between means was determined at a significance level of $\mathrm{p}=0.05$ for the morphometric features and health. In the case of the gas exchange parameters, means were classified into homogeneous groups using the Newman-Keuls test. Letter designations $(\mathrm{A}, \mathrm{B}, \mathrm{C} \ldots)$ are used in the tables to designate statistically significant differences between means (means followed by the same letter are not significantly different at $\alpha=0.01$ ). Pearson's linear correlation was used to examine the strength of the relationships between the investigated traits.

\section{RESULTS}

The analysis of the morphometric features of pea showed that the application of Effective Microorganisms had a significant effect on the morphometric traits of pea. Seed dressing with Effective Microorganisms, combined with chemical control, significantly increased plant height and first pod height (Table 1). The highest average number of pods per plant was obtained in the same treatment as well as in the treatment combination in which Effective Microorganisms were applied without chemical control. A triple application of EM1 without chemical control and the integration of EM1 soil application with chemical control had a significant impact on the number of seeds per pod and number of seeds per plant. The lowest values of all the morphometric features in question were recorded for the control treatments and the treatments with chemical control alone.

The application of Effective Microorganisms had a significant impact on the values of the gas exchange parameters under investigation (Table 2). The highest values for the photosynthesis rate $A n$ $\left(14.0 \mu \mathrm{mol} \mathrm{CO} \mathrm{CO}^{-2} \times \mathrm{s}^{-1}\right)$, molar transpiration rate E $\left(4.42 \mathrm{mmol} \mathrm{H}_{2} \mathrm{Om}^{-2} \times \mathrm{s}^{-1}\right)$, and stomatal conductance $G s\left(0.18 \mathrm{mmol} \mathrm{H}_{2} \mathrm{Om}^{-2} \times \mathrm{s}^{-1}\right)$ were found in the case of EM1 foliar application combined with chemical control while, as regards intercellular $\mathrm{CO}_{2}$ concentration [265.32 $\mu \mathrm{mol} \mathrm{CO} \mathrm{m}^{-2} \times \mathrm{s}^{-1}$ ], in the treatment combination in which pea seeds had been treated with EM1. The lowest value of the rate An was noted in the pea plants whose seeds had been dressed with the biological preparation EM1, whereas in the case of the molar transpiration rate $\mathrm{E}$ in the treatment with EM1 soil application combined with chemical control. The lowest values of the rates $G s$ and $C i$ were recorded in the case of the application of chemical protection. The analysis of Pearson's linear correlation showed that there was a small relationship between gas exchange rates and number of seeds per pod, which is confirmed by the values of the correlation coefficients amounting to $\mathrm{R}=0.32$ for the rate of photosynthesis, $\mathrm{R}=0.38$ - for molar transpiration, $\mathrm{R}=0.45$ for stomatal conductance, and $\mathrm{R}=0.43$ for intercellular $\mathrm{CO}_{2}$ concentration (Fig. 1 . $a, b, c, d)$.

In this pot experiment, the occurrence of only Fusarium wilt of pea (Fusarium spp) was found throughout the study years (Table 3). It was demonstrated that the method of application of Effective Microorganisms significantly affected the severity of disease symptoms. Soil application of EM1 combined with chemical control was found to be the most effective in reducing Fusarium canker symptoms $(\mathrm{Ip}=5.6 \%)(\mathrm{Tab}-$ le 3). The highest infection index by far, amounting to $\mathrm{Ip}=14 \%$, was found in the control treatment. The statistical analysis also confirmed that the incidence of Fusarium wilt of pea slightly decreased the number of seeds per pod $(\mathrm{R}=-0.41)$. The existence of a negative correlation was also found between the severity of Fusarium wilt of pea and the gas exchange parameters: photosynthesis rate $A n(R=-0.29)$, molar transpiration rate $\mathrm{E}(\mathrm{R}=-0.35)$, stomatal conductance $(\mathrm{R}=-0.38)$, and intercellular $\mathrm{CO}_{2}$ concentration $(\mathrm{R}=-0.39)$, but the obtained results were not statistically significant.

318 fungal colonies were isolated from the infected pea stems in this pot experiment (Table 4). Fungi known to be pathogenic made up the largest group among the isolated species, accounting for $83.96 \%$. Fusarium oxysporum was the most frequently isolated fungus among them (58.49\%); its presence in the tissues of the infected plants was also confirmed by microscopic analysis (Fig. 1a,b). Fungi known to be antagonistic to soil pathogens accounted in total for $9.75 \%$ of all isolates. Pathogenic species comprised the largest percentage in the following treatments: plants sprayed with the suspension of Effective Microorganisms (97.82\%) and the control treatment $(90.32 \%)$, while the lowest percentage was found in the following treatments: with soil application of EM $(75.92 \%)$ and in the chemical control treatment $(76.47 \%)$. 
Table 1

Average means of selected morphometric features of pea after EM1 application

\begin{tabular}{cccccc}
\hline Treatment & Plant height & First pod height & $\begin{array}{c}\text { Number of pods } \\
\text { per plant }\end{array}$ & $\begin{array}{c}\text { Number of seeds } \\
\text { per pod }\end{array}$ & $\begin{array}{c}\text { Number of seeds } \\
\text { per plant }\end{array}$ \\
\hline $1^{*}$ & 74.1 & 66.1 & 2.3 & 3.0 & 6.3 \\
2 & 92.1 & 77.6 & 3.0 & 2.7 & 7.8 \\
3 & 78.0 & 68.3 & 2.0 & 2.7 & 5.2 \\
4 & 85.6 & 74.5 & 3.0 & 3.1 & 9.0 \\
5 & 71.3 & 60.2 & 2.5 & 2.2 & 5.0 \\
6 & 70.7 & 62.5 & 1.9 & 2.1 & 3.8 \\
\hline Nir 0.05 & 7.8 & 7.4 & 0.8 & 0.6 & 2.2 \\
\hline
\end{tabular}

*1. soil treated with Effective Microorganisms (EM)

2. seeds treated with EM1

3. foliage treated with EM1

4. soil. foliage and seeds treatment with EM1

5. control

6. pesticide control

Table. 2

Gas exchange parameters of Ramrod variety pea after EM1 application

\begin{tabular}{ccccc}
\hline Treatment & $A n$ & $E$ & $G s$ & $C i$ \\
\hline $1^{*}$ & $10.92 \mathrm{CD} \pm 1.09$ & $3.08 \mathrm{E} \pm 0.45$ & $0.13 \mathrm{E} \pm 0.02$ & $244.34 \mathrm{D} \pm 5.26$ \\
2 & $9.84 \mathrm{E} \pm 1.18$ & $3.35 \mathrm{D} \pm 0.57$ & $0.14 \mathrm{D} \pm 0.03$ & $265.32 \mathrm{~A} \pm 4.75$ \\
3 & $14.28 \mathrm{~A} \pm 1.20$ & $4.42 \mathrm{~A} \pm 0.94$ & $0.18 \mathrm{~A} \pm 0.05$ & $250.30 \mathrm{C} \pm 4.22$ \\
4 & $12.61 \mathrm{~B} \pm 2.17$ & $3.84 \mathrm{~B} \pm 0.56$ & $0.16 \mathrm{~B} \pm 0.03$ & $258.57 \mathrm{~B} \pm 2.78$ \\
5 & $11.05 \mathrm{C} \pm 1.78$ & $3.64 \mathrm{C} \pm 0.47$ & $0.15 \mathrm{C} \pm 0.03$ & $251.99 \mathrm{C} \pm 3.75$ \\
6 & $10.35 \mathrm{DE} \pm 1.71$ & $3.28 \mathrm{DE} \pm 0.63$ & $0.13 \mathrm{E} \pm 0.03$ & $241.15 \mathrm{E} \pm 6.66$ \\
\hline
\end{tabular}

$1 *$ explanations in Table 1

Table 3

Occurrence of Fusarium wilt symptoms on the pea stem base (Ip \%) after EM1 application

\begin{tabular}{ccccc}
\hline Treatment & 2002 & 2003 & 2004 & $X$ \\
\hline $1^{*}$ & 3.25 & 8.25 & 5.25 & 5.58 \\
2 & 6.75 & 11.75 & 9.25 & 9.25 \\
3 & 4.25 & 9.25 & 7.00 & 6.83 \\
4 & 8.50 & 12.50 & 9.00 & 10.00 \\
5 & 12.00 & 16.50 & 13.50 & 14.00 \\
6 & 7.25 & 10.75 & 7.25 & 8.42 \\
\hline Nir 0,05 & 3.54 & 3.30 & 2.95 & 1.82 \\
\hline
\end{tabular}

$1 *$ explanations in Table 1 
Table 4

Fungi isolated from infected pea tissues after EM1application

\begin{tabular}{|c|c|c|c|c|c|c|c|}
\hline \multirow{2}{*}{ Fungal species } & \multicolumn{6}{|c|}{ Treatment } & \multirow{2}{*}{ Subtota } \\
\hline & $1 *$ & 2 & 3 & 4 & 5 & 6 & \\
\hline 1 Alternaria altrnata (FR. ex Fr.) Keiss. & & & & 2 & & & 2 \\
\hline 2 Artrinium sphaerospermum Fuckel & & & & 2 & & & 2 \\
\hline 3 Aspergillus niger van Tieghem & & 1 & & & & & 1 \\
\hline 4 Aspergillus oryzae (Ahlburg) Cohn. & & & 1 & & & & 1 \\
\hline 5 Eladia saccula (Dale) G. Smith & 1 & & & & & 2 & 3 \\
\hline 6 Endothia sp. & 1 & & & & & & 1 \\
\hline 7 Fusarium culmorum (W. G. Smith) Sacc. & 1 & 2 & & & & 6 & 9 \\
\hline 8 Fusarium dimerum Penzig & 1 & & 5 & & & & 6 \\
\hline 9 Fusarium equiseti Corda Sacc. & 4 & & & 7 & 2 & & 13 \\
\hline 10 Fusarium fusarioides Frag., Cif. & & & 1 & & & & 1 \\
\hline 11 Fusarium oxsysporum Schlecht & 22 & 23 & 26 & 40 & 50 & 25 & 186 \\
\hline 12 Fusarium poae (Peck) Wollenweber & & & 3 & & & 4 & 7 \\
\hline 13 Fusarium solani (Mart.) Sacc. & 10 & 6 & 8 & 0 & & & 24 \\
\hline 14 Fusarium solani var. coeruleum (Libert) Bilai & 1 & 2 & 2 & 4 & & 4 & 13 \\
\hline 15 Fusarium sporotrichoides (Sherbakoff) & 1 & & & & & & 1 \\
\hline 16 Gliocladium catenulatum Corda & 4 & & & 1 & & & 5 \\
\hline 17 Gliocladium fimbriatum Gilman et Abbott & & 1 & & & & 1 & 2 \\
\hline 18 Gliocladium penicilliodes Corda & 5 & 2 & & 7 & 6 & 1 & 21 \\
\hline 19 Gliomastix murorum (Corda) Hughes & & & & & & 2 & 2 \\
\hline 20 Humicola brevis Gilman and Abbott & 2 & & & 1 & & & 3 \\
\hline 21 Microdochim nivale (Fr.) Ces. & 1 & & & & & & 1 \\
\hline 22 Mortierella alpina Peyrond & & & & 2 & & 1 & 3 \\
\hline 23 Mucor circinelloides van Tieghem & & 2 & & & & & 2 \\
\hline 24 Phoma medicarginis var. pinodella (L. K. Jones) & & & & & 2 & & 2 \\
\hline 25 Rhizoctonia solani Kühn & & & & & 2 & & 2 \\
\hline 26 Trichoderma koningi Oudemans & & & & & & 3 & 3 \\
\hline Sum & 54 & 39 & 46 & 66 & 62 & 51 & 318 \\
\hline
\end{tabular}

$1 *$ explanation in table 1 

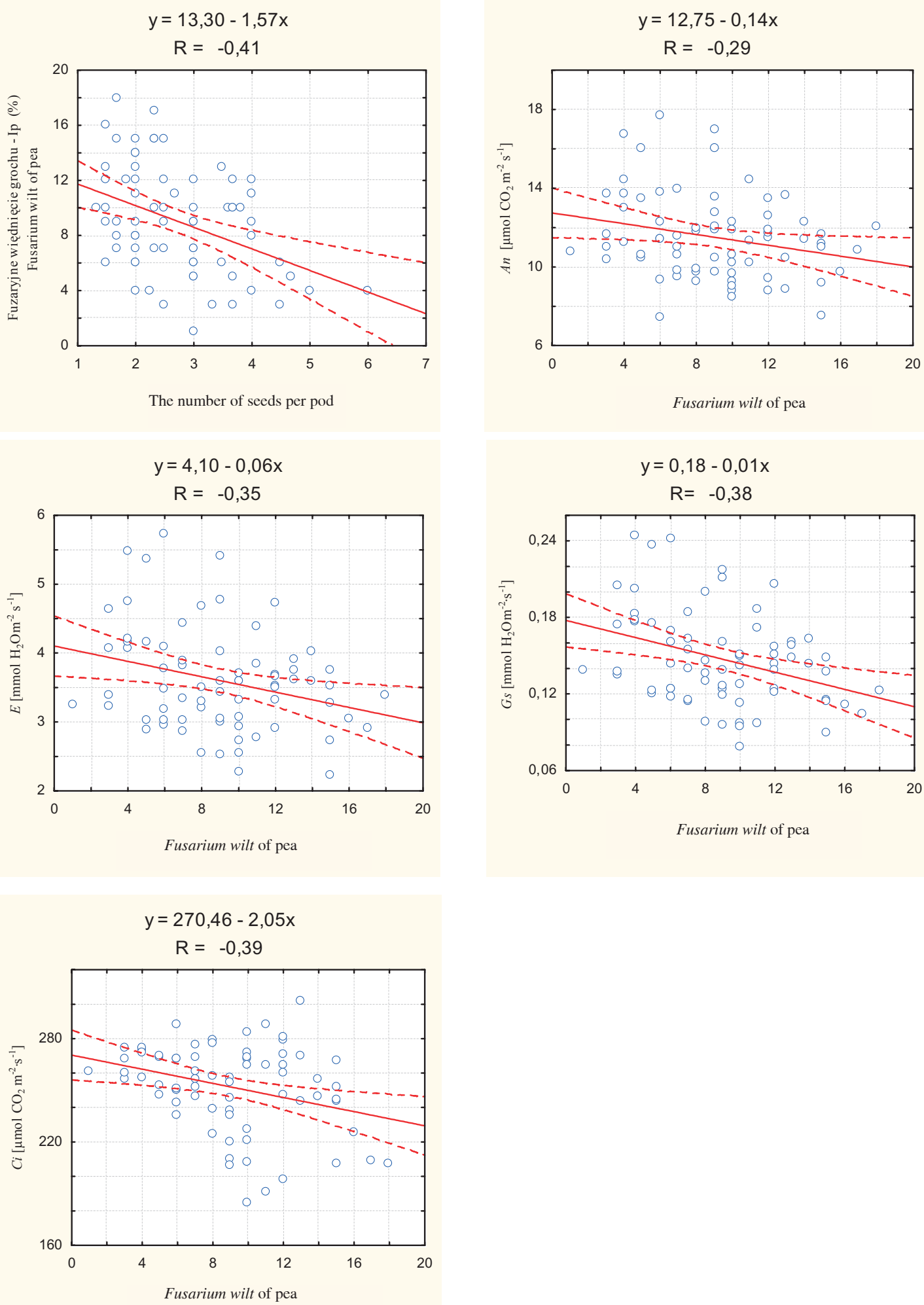

Fig. 1. Linear regression between number of seeds per pod and gas exchange parameters: (a) net photosynthesis rate (b) molar transpiration rate; (c) stomatal conductance; (d) intercellular $\mathrm{CO}_{2}$ concentration 

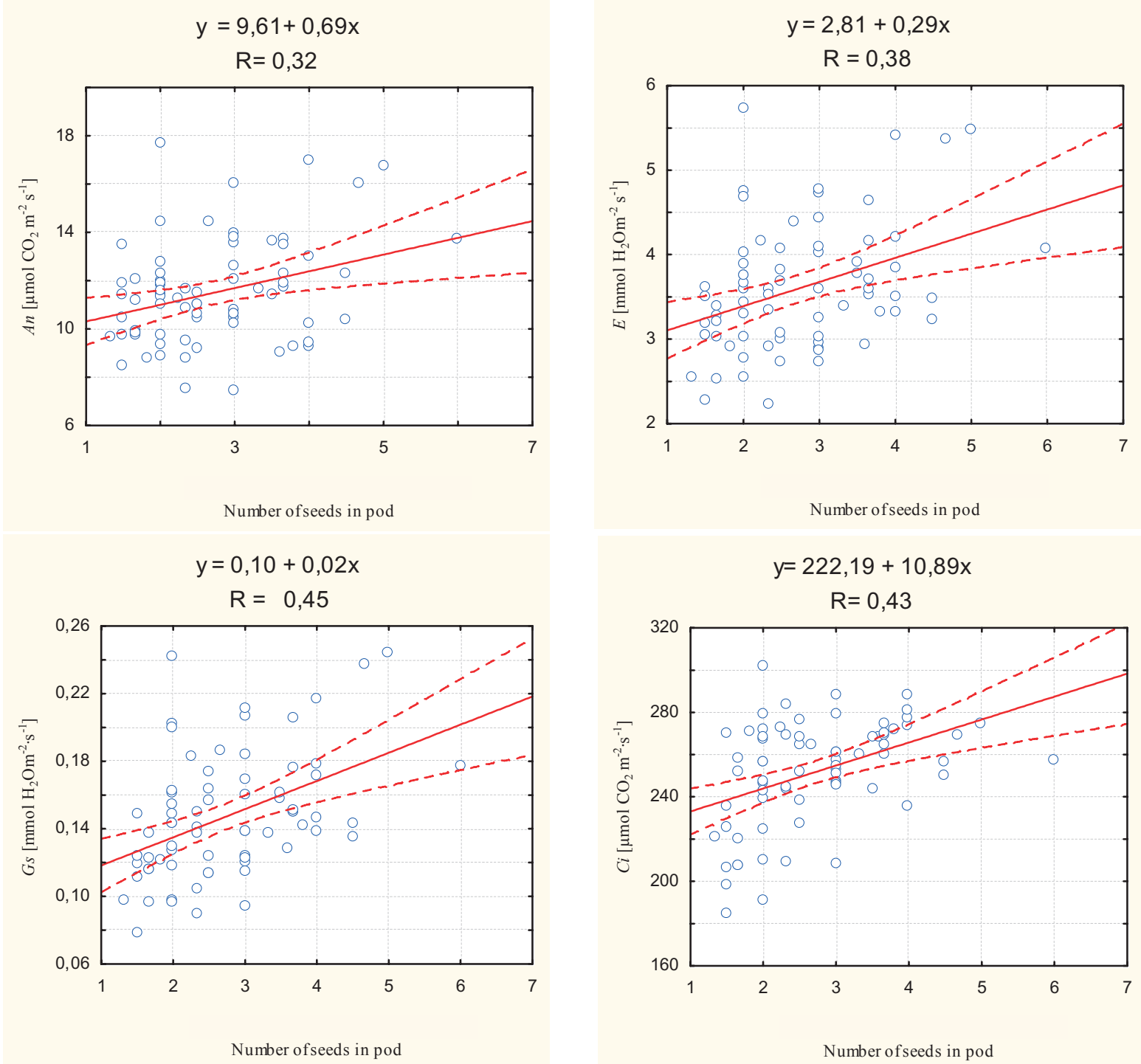

Fig. 2. Linear regression between number of seeds per pod and gas exchange parameters: (a) net photosynthesis rate (b) molar transpiration rate; (c) stomatal conductance; (d) intercellular $\mathrm{CO}_{2}$ concentration 

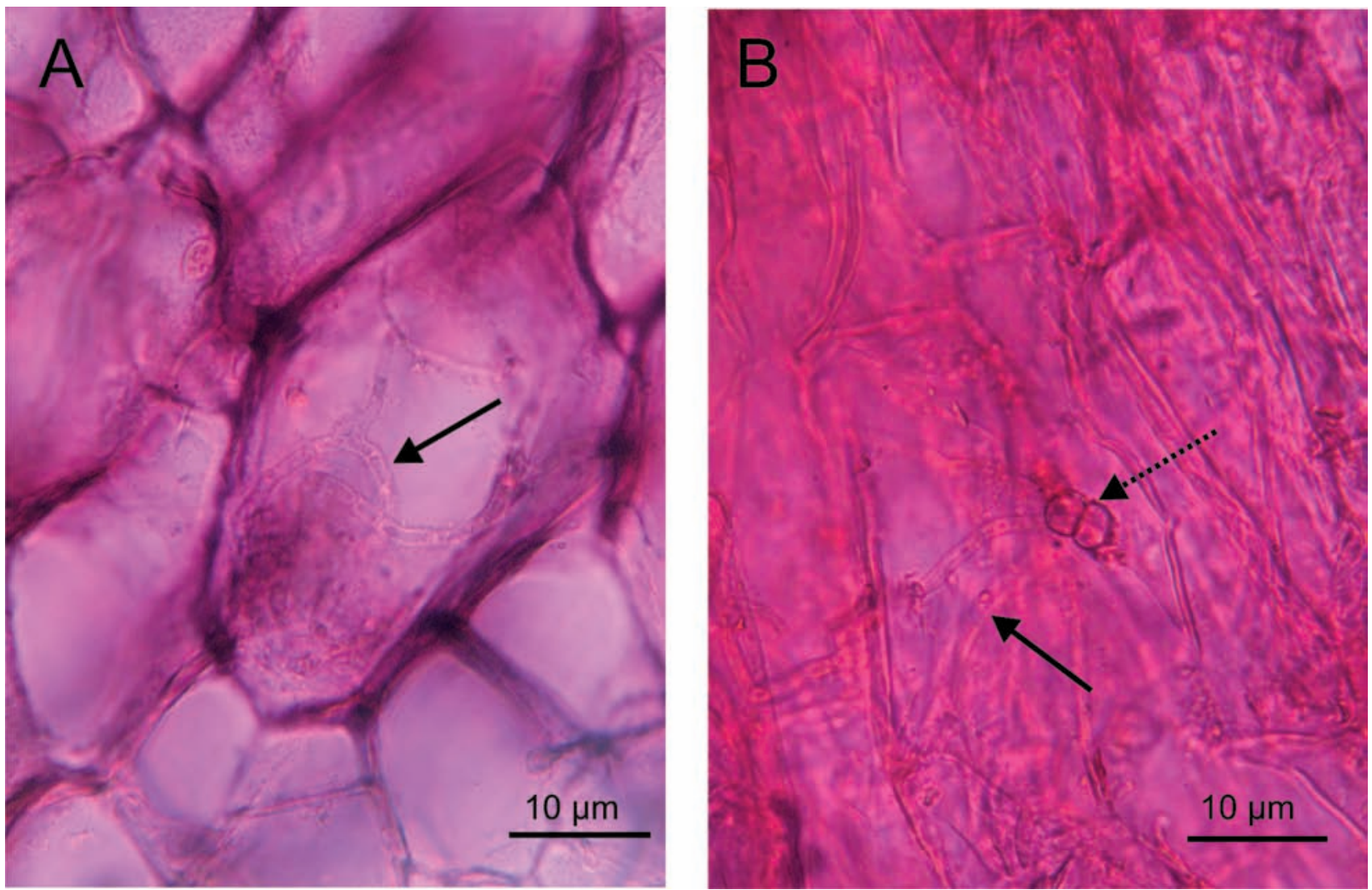

Fig. 3. Cross sections of the base of the Pisum sativum stem infected of Fusarium oxysporum a) cortex parenchyma cells with hyphae (arrows) - early infection; b) cortex parenchyma cells with hyphae (arrows) and chlamydospores (dotted arrow) - late infection

\section{DISCUSSION}

In the present pot experiment, the incidence of Fusarium wilt of pea was observed in all the years of the study. It was shown that the method of application of the biological control agent EM1 had a significant effect on the severity of disease symptoms, while $F u$ sarium oxysporum was the most frequently isolated species from the infected tissues of pea. Similar results were obtained by Errampalli and Brubacher (2006) who found that the integration of biological control with chemical control of pathogens allowed the efficacy of plant protection to be enhanced. Fungi of the genus Fusarium belong to typical plant pathogens found on many plant species in all climatic zones. Dying of plants as a result of infection caused by fungi of the genus Fusarium can result from the blockage of vascular bundles, which dramatically limits their life functions and can also be related to toxin synthesis by this fungal genus. Fusarium oxysporum infects plant roots, penetrating into primary cortex, and then grows through vascular tissues (D i Pietro et al. 2003). In the opinion of Beckman (1987), macroconidia play an important role in the colonization of xylem tissues by fungi of the genus Fusarium. In our own study, there were observed mycelium hyphae growing through the primary cortex cells at the initial stage of infection, while in the case where strong symptoms of Fusarium wilt occurred, the fungus Fusarium oxysporum formed chlamydospores in the parenchymal tissue. But no presence of microconidia and macroconidia was observed. The results of the microscopic analysis performed in the present study are also confirmed by the studies of C z y mmek et al. (2007) and van der D oes et al. (2008) who identified the presence of Fusarium oxysporum chlamydospores in the tissues of tomato and Arabidopsis thaliana but, at the same time, they did not observe microconidia or macroconidia.

The application of the biological preparation EM1 had a significant effect on the values of all the gas exchange parameters under study. The highest values for the rates of net photosynthesis, molar transpiration, stomatal conductance, and intercellular $\mathrm{CO}_{2}$ concentration were found in the case of foliar application of Effective Microorganisms combined with chemical control. Similar results were obtained by $\mathrm{X} u$ et 
al. (2000) who observed a higher photosynthesis rate in the treatments in which EM1 inoculation had been used, compared to the control treatment. The activity of rhizosphere microorganisms is closely associated with plant metabolism. They affect nutrient transformations in soils and have a major influence on root formation. The increased availability and better uptake of minerals directly affect the photosynthesis process. Rhizospheric microbes enable better uptake of nutrients and their movement in plants (E $1-\mathrm{S} \mathrm{h}$ a t$\mathrm{nawi}$ and $\mathrm{Makhadmeh}, 2001)$. The application of antagonistic microorganisms has a direct effect on the photosynthesis rate and plays a protective role against pathogenic fungi growing in the phyllosphere. E1 - T a r a bily et al. (1997) showed that Micromonospora spp. reduced the growth of plant pathogens as a result of it having competitive properties in relation to this group of microorganisms, or through the activation of plant systemic resistance.

Stress conditions may have an adverse effect on the photosynthesis rate ( $\mathrm{M} \mathrm{ax} \mathrm{w} \mathrm{e} 11$ and $\mathrm{J} \mathrm{oh} \mathrm{n} \mathrm{s} \mathrm{o} \mathrm{n,}$ 2000). In our own study conducted under natural infection conditions, Fusarium wilt of pea occurred at a relatively low level and, as a result of that, the relationship between gas exchange parameters and infection of pea plants with $F$. oxysporum was insignificant. The increased occurrence of disease symptoms insignificantly decreased all the gas exchange parameters under study. A reduction in the photosynthesis rate as a result of infection of the plants with Fusarium spp., observed in the study of W a g n e r et al. (2006), was probably attributable to damage of the mesocotyl tissues and to systemic plant infection that inhibited water and assimilate transport.

In our own study, seed dressing with the biological control agent and chemical control had a beneficial impact on the number of pods per plant and number of seeds per plant, but in the case of this treatment there was found only a slight reduction in the incidence of Fusarium wilt of pea. Similar correlations were observed by M u elle r and B radle y (2008) who found that although seed dressing protected plants against pathogens only for a limited time period, but it had a beneficial influence on plant productivity. Such a thesis is also confirmed by the study of R o d ri g u e z-Brljevich et al. (2010) who found that the seed treatment fungicide Crusier Extreme 250 (fludioxonil + azoxystrobin + mefenoksam + thiamethoxam) reduced infestation of maize plants with Fusarium spp. and also had a beneficial effect on the photosynthesis process and plant vigour. P s h i b y t k o et al. (2006) observed decreased photosynthetic capacity of tomato plants as a result of infection of the plants with $\mathrm{F}$. oxysporum; they also found that the disease destroyed photosynthetic pigments and led to the disturbance of water management in the plants. Infected plants close their stomata, which is accompanied by the reduced activity of Rubisco. Jila n i et al. (2007) report that, from the economic point of view, the most advantageous solution is to apply EM technology jointly with organic and chemical fertilizers at supplementary doses that would meet the nutrient requirements of plants. In our own study conducted under controlled conditions, we found that EM1 doses recommended by the manufacturer had a beneficial impact on the morphometric traits of pea, while the most beneficial method of EM1 application was pre-sowing soil application of this biological control agent combined with chemical control. There are also reports claiming that there is no beneficial effect of Effective Microorganisms on plant productivity and soil microbiological activity as well as only a slight positive influence on the process of nitrogen mineralization ( $\mathrm{Schenck} \mathrm{zu} \mathrm{Schwein-}$ sberg-Mickan and Muller, 2009). Formow it z et al. (2007) explain the absence of a beneficial effect of Effective Microorganisms on the mineralization processes by too low an amount of microorganisms (the agent components) introduced into the soil to be able to dominate the native microbiota of the soil environment. Such suppositions are also confirmed by the study of O k or s ki and M a j c hr z a k (2007) which shows that EM1, in a field study, only slightly affected the native soil microbiota. In the opinion of $\mathrm{K}$ a c z m a r e k et al. (2008), the efficacy of this biological preparation is related to its dose and soil type.

\section{CONCLUSIONS}

1. The integration of EM1 soil application with chemical control proved to be the best application method to reduce the incidence of Fusarium wilt of pea and to have the most beneficial effect on yield-related morphometric features.

2. Foliar application of EM1 combined with chemical control significantly increased the more important gas exchange parameters.

3. The increased incidence of Fusarium wilt of pea had an insignificant effect on the reduction in the gas exchange parameters and the number of seeds per plant.

\section{REFERENCES}

B e ck m a n C. H., 1987. The Nature of Wilt Diseases of Plant. St. Paul: APS Press.

Czy m mek K. J., Fogg M., Powell D. H., Sweig ard J., Park S. Y. and Kang, S., 2007. In vivo time-lapse documentation using confocal and multi-photon microscopy reveals the mechanisms of invasion into the Arabidopsis root vascular system by Fusarium oxysporum. Fungal Genet. Biol. 44: 1011-1023. 
Da is s N. M., Lobo M. G., S o c orro A. R., Brukner U., Heller J., Gonzalez M., 2008. The effect of three organic pre-harvest treatments on Swiss chard (Beta vulgaris L. var. cycla L.) quality. Eur. Food. Res. Technol. 226: 345-353.

Daly M. J., Stewart D. P. C., 1999: Influence of "effective microorganisms" (EM) on vegetable production and carbon mineralization - a preliminary investigation. J. Sustain. Agric. 14, 15-25.

Di Pietro A., Madrid M. P., Caracuel Z., Delgado - Jar a n a J., Roncero M. I. G., 2003. Fusarium oxysporum: exploring the molecular arsenal of a vascular wilt fungus. Mol. Plant Pathol. 4: 315-325.

van der Does H.C., Duyvesteijn R. G. E., Goltstein P. M., van Schie C. C. N., Manders E. M. M., Cornelissen B. J. C. Rep M., 2008. Expression of effector gene SIX1 of Fusarium oxysporum requires living plant cells. Fungal Genet. Biol. 45: 1257-1264.

E1-Sh at n aw i M. K. J., M a k h a d m e h I. M., 2001. Ecophysiology of the Plant-Rhizosphere System. J. Agronomy \& Crop Science, 187: 1-9.

E1-Tarabily K. A., Hardy G. E. St. J., Sivasithamparam K., Hussein A. M. Kurtboke I. D., 1997. The potential for the biological control of cavity spot disease of carrots caused by Pythium coloratum by streptomycete and nonstreptomycete actinomycetes in Western Australia. New Phytol. 137: 495-507.

Errampalli D., Brubacher N. R., 2006. Biological and integrated control of postharvest blue mold (Penicillium expansum) of apples by Pseudomonas syringae and cyprodinil. Biological Control. 36: 49-56.

Formowitz B., Elano F., Okumoto S., Muller T., Buerkert A., 2007. The role of "effective microorganisms" in the composting of banana (Musa ssp.) residues. J. Plant Nutr. Soil Sci. 170: 649-656.

Hillstrand D. S., Auld D. J., 1982. Comparative evaluation of four techniques for screening winter peas for resistance to Phoma medicaginis var. pinodella. Crop Sci., 22 (2): 282-287.

Jilani G., Akram A., Ali R. M., Hafeez F. Y., Shamsi I. H., Chaudhry A. N., Chaudhry A. G., 2007. Enhancing crop growth, nutrients availability, economics and beneficial rhizosphere microflora through organic and biofertilizers. Ann. Microbiol. 57 (2): 177-183.

Kaczmarek Z., Jakubas M., Grzelak M., Mrugalsk a L., 2008. Impact of the addition of various doses of Effective Microorganisms to arable-humus horizons of mineral soils on their physical and water properties. J. Res. and Appl. in Agric. Eng. 53 (3): 118-121.

Łacicowa B., 1969. Laboratory method of quick evaluation of barley resistance to Helminthosporium sativum. Biul. IHAR, 3 (4): 61-62.

Maxwe11, K., John son, G. N., 2000. Chlorophyll fluorescence a practical guide. Experim. Bot. 51: 659-668.

Muelle r D. S., B r a d l e y C. A., 2008. Field crop fungicides for the North Central States (29). North Central IPM Center: Champaign.
Okorski A., M aj chrzak B., 2007. Fungi isolated from soil before the seeding and after harvest of pea (Pisum sativum L.) after application of bio-control product EM $1^{\mathrm{TM}}$. Acta Agrobot. 60 (1): 113-121.

Okorski A., Majchrzak B., 2008. Grzyby zasiedlające nasiona grochu siewnego po zastosowaniu preparatu mikrobiologicznego EM 1. / Fungi colonizing pea seeds after the application of the microbiological control agent EM1. Progress in Plant Prot. 48 (4): 1314-1318 (in Polish).

Pshibytko N. L., Zenevich L. A., Kabashnikova L. F., 2006. Changes in the Photosynthetic Apparatus during Fusarium Wilt of Tomato. R. J. Plant Physiol. 53 (1): 25-31.

Rodriguez-Brljevich C., Kanobe C., Shanahan J. F., Robertson A. E., 2010. Seed treatments enhance photosynthesis in maize seedlings by reducing infection with Fusarium spp. and consequent disease development in maize. Eur. J. Plant. Pathol. 126: 343-347.

Schenck zu Schweinsberg-Mickan M., Muller T., 2009. Impact of effective microorganisms and other biofertilizers on soil microbial characteristics, organicmatter decomposition, and plant growth. J. Plant Nutr. Soil Sci. 172: 704-712.

Strange R. N., Scott P. R., 2005. Plant disease: A threat to global food security. Ann. Rev. Phytopathol. 43: 83-116.

Wagner A., Michalek W., Jamiolkowska A., 2006. Chlorophyll fluorescence measurements as indicators of fusariosis severity in tomato plants. Agronomy Research, 4: 461-464.

Xu H. L, Wang R., Mridha M. A. U., Kato S., Kat ase K., Umemura H., 2000. Effect of organic fertilization and EM inoculation on leaf photosynthesis and fruit yield and quality of tomato plants. Proceedings of the 6th International Conference on Kyusei Nature Farming, South Africa, 1999 Y. D. A. Senanayake, U. R. Sangakkara.

\section{Wpływ preparatu mikrobiologicznego EM1 na wskaźniki wymiany gazowej, produktywność oraz występowanie fuzaryjnego więdnięcia grochu siewnego (Fusarium oxysporum)}

\section{Streszczenie}

Doświadczenie prowadzono w latach 20022004 w szklarni komputerowej UWM w Olsztynie. Obiektem badań był groch siewny odmiany Ramrod, a czynnikiem doświadczenia sposób aplikacji efektywnych mikroorganizmów [EM1]. Biopreparat EM1 przed zastosowaniem namnożono zgodnie $\mathrm{z}$ zaleceniami producenta (Greenland). Badania obejmowały ocenę zdrowotności roślin grochu w fazie kwitnienia, wskaźników wymiany gazowej przy użyciu analiza- 
tora gazowego Li-Cor 6400, analizy mikologiczne i mikroskopowe obserwacje porażenia roślin, a także pomiar wybranych cech morfometrycznych grochu. W badaniach wykazano, że na występowanie fuzaryjnego więdnięcia grochu istotnie wpływał sposób stosowania preparatu EM1. Najskuteczniejsze w ograniczeniu choroby okazało się połączenie aplikacji doglebowej z chemiczną ochroną. Nalistna aplikacja EM w połączeniu z ochroną chemiczną zwiększała wartości wszystkich badanych wskaźników wymiany gazowej. Występowanie fuzaryjnego więdnięcia nieznacznie wpływało na ograniczenie wartości wszystkich badanych wskaźników wymiany gazowej oraz na liczbę nasion w strąku. Najkorzystniejszym dla cech morfometrycznych związanych z plonem sposobem aplikacji preparatu biologicznego EM1 było połączenie aplikacji doglebowej $\mathrm{z}$ chemiczną ochroną. 
